\title{
Pengaruh Pemupukan N, P, dan K pada Dua Varietas Benih Kedelai (Glycine Max (L) Merr.) terhadap Kandungan Antosianin dan Hubungannya dengan Vigor Benih
}

\section{Effect of N, P, and K Fertilization in Two Varieties of Soybeans (Glycine max (L) Merr.) Seeds on Anthocyanin Content in Relation to Seed Vigor}

\author{
Sophia Fitriesa, Maryati Sari", dan M.R. Suhartanto \\ Departemen Agronomi dan Hortikultura, Fakultas Pertanian, Institut Pertanian Bogor \\ (Bogor Agricultural University), Jl. Meranti, Kampus IPB Darmaga, Bogor 16680, Indonesia \\ Telp.\&Faks.62-251-8629353 e-mail agronipb@indo.net.id \\ *Penulis untuk korespondensi : maryatisari@yahoo.co.id
}

Disetujui 16 Januari 2017/ Published Online 24 Januari 2017

\begin{abstract}
The purpose of this research was to study the effect of $N, P$, and $K$ fertilization on the content of anthocyanin and seed vigor on two soybean varieties in order to look for a correlation between them. The research was conducted at IPB Experiment Station in Leuwikopo and Seed Technology Laboratory AGH, IPB on Februari until July 2011. The design which used in this experiment is Split Plot Design. The first factor is soybean varieties (Anjasmoro and Detam 1). The second factor is NPK fertilization (no fertilizer, $N P K, N P, N K$, and PK). Observations included vegetative observations and production of seed, anthocyanin content of seed, seed viability, vigor of growth strength and storability vigor of the seeds. The result of this study showed that varieties effect on anthocyanin content of seed. Varieties Detam 1 shows the anthocyanin content is higher than Anjasmoro varieties. Application of fertilizer effect on storability vigor of soybean seeds through controlled deterioration. Application of NPK and NK fertilizer give the highest value for storability vigor of the seeds $(83.33 \%$ and $80.00 \%)$ higher than the lowest storability vigor of the seeds produced by no fertilizer treatment (61.33\%). Electroconductivity is not affected by the provision of fertilizer and varieties but affected by the interaction of both. Correlation was not found between anthocyanin content and seed vigor.
\end{abstract}

Keywords : Anjasmoro Soybean, Detam 1 soybean, NPK Fertilization, Anthocyanin, Controlled Deterioration

\section{ABSTRAK}

Tujuan dari penelitian ini adalah untuk mempelajari pengaruh pemupukan $N, P$, dan $K$ pada kandungan antosianin dan vigor benih pada dua varietas kedelai untuk mencari korelasi antara mereka. Penelitian ini dilaksanakan Kebun Percobaan Leuwikopo IPB dan Laboratorium Teknologi Benih AGH, IPB pada Februari sampai Juli 2011. Rancangan yang digunakan dalam penelitian ini adalah Rancangan Split Plot. Faktor pertama adalah varietas kedelai (Anjasmoro dan Detam 1). Faktor kedua adalah pemupukan NPK (tanpa pupuk, NPK, NP, NK, dan PK). Pengamatan meliputi pengamatan vegetatif dan produksi benih, kandungan antosianin benih, viabilitas benih, vigor kekuatan tumbuh dan vigor daya simpan benih. Hasil penelitian ini menunjukkan bahwa varietas berpengaruh pada kandungan antosianin benih. Varietas Detam 1 menunjukkan kandungan antosianin lebih tinggi dari varietas Anjasmoro. Aplikasi pupuk berpengaruh pada vigor daya simpan dari biji kedelai melalui pengusangan terkontrol. Aplikasi NPK dan pupuk NK memberikan nilai tertinggi untuk vigor daya simpan dari biji (83,33\% dan 80,00\%) lebih tinggi dari vigor daya simpan terendah yang dihasilkan oleh perlakuan tanpa pemupukan (61,33\%). Elektrokonduktivitas tidak terpengaruh oleh pemberian pupuk dan varietas tetapi dipengaruhi oleh interaksi dari keduanya. Korelasi tidak ditemukan antara kandungan antosianin dan vigor benih. 


\section{PENDAHULUAN}

Kedelai (Glycine Max (L.) Merr.) merupakan sumber utama protein nabati di Indonesia. Kebutuhan konsumsi kedelai untuk bahan pangan masyarakat Indonesia dan pakan ternak meningkat setiap tahunnya. Produksi kedelai di tahun 2010 sebesar 908111 ton dan diperkirakan meningkat pada tahun 2011 menjadi 934003 ton, akan tetapi kenaikan produksi tersebut masih belum bisa memenuhi kebutuhan konsumsi masyarakat yang mencapai 2.2 juta ton per tahun (Badan Pusat Statistik, 2011). Hingga saat ini Indonesia masih tergantung pada impor untuk pemenuhan kebutuhan kedelai dalam negeri. Dalam rangka mewujudkan swasembada kedelai yang ditargetkan tercapai pada tahun 2015 perlu adanya peningkatan produksi melalui upayaupaya seperti peningkatan luas areal pertanaman (ekstensifikasi) dan juga penerapan teknologi budidaya kedelai yang dapat meningkatkan produktivitasnya (intensifikasi).

Ketersediaan benih bermutu menjadi bagian penting dalam rangka intensifikasi kedelai. Kurang tersedianya benih bermutu menjadi salah satu sebab rendahnya rata-rata produktivitas kedelai. Kini rata-rata produktivitas kedelai nasional baru mencapai 1.37 ton ha ${ }^{-1}$ (Badan Pusat Statistik, 2011), sementara potensi produksi beberapa varietas unggul sebenarnya cukup tinggi misalnya varietas Detam 1 mempunyai potensi produksi sebesar 3.5 ton ha $^{-1}$, Detam 2 sebesar 3 ton $\mathrm{ha}^{-1}$, Wilis sebesar 1.6 ton $\mathrm{ha}^{-1}$, Cikuray sebesar 1.7 ton $\mathrm{ha}^{-1}$, dan Anjasmoro sebesar 2.3 ton ha ${ }^{-1}$ (Balitkabi, 2008).

Cepatnya kemunduran benih merupakan masalah utama dalam produksi benih (Copeland dan McDonald, 2001). Menurut Kartono (2004) penyimpanan benih kedelai dengan kadar air awal $8 \%$ pada ruang biasa dapat disimpan hingga 3 tahun tanpa menurunkan perkecambahannya, sedangkan benih kedelai dengan kadar air awal lebih dari $12 \%$ daya kecambah akan turun menjadi $60 \%$ setelah disimpan 1 tahun dan menjadi $0 \%$ setelah 3 tahun. Pada kenyataannya, daya simpan benih kedelai sangat rendah sehingga BPSB hanya menerapkan masa berlaku label selama 3 bulan (Deptan, 2010). Permasalahan mengenai rendahnya daya simpan benih kedelai menjadi hambatan dalam pengadaan benih bermutu dari varietas unggul.

Salah satu yang diduga dapat menunda kemunduran benih adalah keberadaan antosianin. Hasil penelitian Mitrowihardjo (1997) menunjukan bahwa antioksidan berpengaruh nyata pada kemunduran buatan dan kemunduran alami pada benih kedelai. Antosianin merupakan salah satu jenis antioksidan. Futura et al. (2002) menyatakan bahwa kedelai berkulit hitam mengandung banyak antosianin. Vigor kedelai hitam lebih tinggi dibandingkan dengan vigor kedelai kuning, hal ini disebabkan karena kandungan antosianin yang tinggi.

Hasil penelitian Mualim et al. (2009) menyebutkan bahwa produksi antosianin daun kolesom dipengaruhi oleh pemupukan. Pemupukan NP (tanpa K) menghasilkan rata-rata produksi antosianin daun kolesom terendah (18.90 mol per tanaman) dan berbeda nyata dengan perlakuan lainnya. Hal ini menunjukkan pada penelitian tersebut unsur $\mathrm{K}$ sebagai faktor pembatas produksi antosianin daun kolesom. Pada penelitian ini akan dipelajari pengaruh setiap unsur dalam pemupukan terhadap kandungan antioksidan, khususnya antosianin serta melihat pengaruhnya terhadap vigor daya simpan benih kedelai. Deteksi vigor dilakukan melalui metode pengusangan cepat terkontrol dan pengujian daya hantar listrik. Metode pengusangan cepat terkontrol dipilih karena menurut ISTA (2007) dapat mengindikasikan vigor daya simpan benih, sedangkan menurut Sadjad et al. (1999) pengujian daya hantar listrik juga dapat mengindikasikan vigor daya simpan benih.

Penelitian ini bertujuan untuk mempelajari pengaruh pemupukan $\mathrm{N}, \mathrm{P}$, dan $\mathrm{K}$ terhadap kandungan antosianin dan vigor benih pada dua varietas kedelai serta keeratan hubungan antara kandungan antosianin benih dengan vigor benih.

\section{METODE PENELITIAN}

Penelitian ini dilaksanakan mulai dari bulan Februari sampai Juli 2011, di Kebun Percobaan Leuwikopo, Darmaga, Laboratorium Ilmu dan Teknologi Benih, serta Laboratorium Analisis Tanaman dan Kromatografi, Departemen Agronomi dan Hortikultura, IPB. Bogor.

Bahan yang digunakan dalam penelitian ini adalah kedelai kuning varietas Anjasmoro dan kedelai hitam varietas Detam 1 yang diperoleh dari BB Biogen. Bahan lainnya yang diperlukan yakni pupuk kandang, pupuk urea, $\mathrm{KCl}, \mathrm{SP}-36$, furadan 3G dengan bahan aktif karbofuron, plastik, dan substrat kertas merang, dan bahanbahan kimia untuk analisis antosianin seperti aseton dan tris. Alat-alat yang digunakan meliputi alat-alat pertanian, water-bath, oven, timbangan digital, spektrofotometer UV-Vis, germinator tipe IPB 72-1, dan electric conductivity meter.

Penelitian ini menggunakan Rancangan Petak Terbagi (Split Plot Design) RKLT dengan tiga ulangan. Perlakuan terdiri dari dua faktor. 
Faktor pertama sebagai petak utama adalah varietas benih kedelai yang terdiri atas, $\mathrm{V} 1$ : Benih kedelai varietas Anjasmoro dan V2: Benih kedelai varietas Detam 1. Faktor kedua sebagai anak petak adalah jenis pemupukan yang digunakan yang terdiri dari kontrol (P0), pupuk $\mathrm{N}, \mathrm{P}$, dan $\mathrm{K}$ (P1), pupuk $\mathrm{N}$ dan $\mathrm{P}(\mathrm{P} 2)$, pupuk $\mathrm{N}$ dan $\mathrm{K}(\mathrm{P} 3)$, dan pupuk $\mathrm{P}$ dan $\mathrm{K}$ (P4). Setiap perlakuan diulang sebanyak tiga kali, sehingga didapatkan sebanyak 30 satuan percobaan. Data yang diperoleh diuji dengan uji $\mathrm{F}$ dan jika menunjukan pengaruh yang nyata, pengujian dilanjutkan dengan Uji Wilayah Berganda Duncan (DMRT) pada taraf 5\%. Uji korelasi dilakukan untuk mengetahui hubungan antara kandungan antosianin dengan vigor benih.

\section{Produksi Benih}

Lahan diolah dan diberi pupuk kandang dengan dosis 3 ton ha $^{-1}$. Setiap satuan percobaan ditanam pada petak berukuran $2 \mathrm{~m}$ x $4.5 \mathrm{~m}$. Jarak antar petak adalah $0.75 \mathrm{~m}$. Pupuk $\mathrm{N}$ yang digunakan adalah urea dengan dosis $25 \mathrm{~kg}$ urea ha $^{-1}$, pupuk P menggunakan SP-36 dengan dosis $150 \mathrm{~kg}$ SP-36 ha ${ }^{-1}$, dan pupuk $\mathrm{K}$ menggunakan $\mathrm{KCl}$ dengan dosis $100 \mathrm{~kg} \mathrm{KCl} \mathrm{ha}^{-1}$. Penetapan dosis ini berdasarkan rekomendasi oleh Balai Penelitian Tanah (2010).

Jarak tanam yang digunakan adalah $40 \mathrm{~cm} \mathrm{x}$ $20 \mathrm{~cm}$ dengan dua benih per lubangnya dan diberikan furadan 3G sebagai insektisida. Pemupukan dilakukan pada saat penanaman. Penyulaman tidak dilakukan untuk menghindari tingkat kemasakan yang tidak seragam. Pemanenan dilakukan saat masak fisiologis. Brangkasan kedelai yang telah dipanen dijemur hingga polong mudah pecah atau biji kering rontok sekitar 3 - 4 hari. Benih dibersihkan dari kotoran dan sisa polong lainnya, kemudian dijemur kembali hingga kadar air $\pm 10 \%$. Pengamatan dilakukan terhadap pertumbuhan vegetatif (tinggi tanaman dan jumlah daun per tanaman) dan produksi (bobot benih per tanaman dan bobot benih per petak).

\section{Pengujian Kandungan Antosianin}

Pengujian kandungan antosianin benih dilakukan dengan menggunakan spektrofotometer dengan menggunakan aseton dan tris sebagai absorbannya. Sampel yang digunakan adalah benih hasil panen dengan kadar air $10 \%$ yang diambil secara acak. Bahan kimia acetris (aseton dan tris $1 \% \mathrm{pH} 8$ dengan perbandingan 85:15) digunakan sebagai pelarut ekstraksi. Cara ekstraksinya adalah dengan melakukan penepungan pada sampel benih lalu setiap $3 \mathrm{~g}$ benih yang telah dihaluskan ditambahkan dengan $5 \mathrm{ml}$ acetris, kemudian dimasukan ke dalam tabung reaksi dan disentrifugasi selama 10 menit. Sebanyak $1 \mathrm{ml}$ supernatan dimasukan ke dalam microtube dan selanjutnya dianalisis dengan spektrofotometer pada panjang gelombang 537 $\mathrm{nm}, 647 \mathrm{~nm}$, dan $663 \mathrm{~nm}$ (Sims dan Gamon, 2002).

Pengujian Viabilitas Potensial dan Vigor Kecepatan Tumbuh

Pengujian mutu benih yang dilakukan dalam penelitian ini adalah untuk mengamati Viabilitas Potensial $\left(\mathrm{V}_{\mathrm{P}}\right)$ dengan tolak ukur Daya Berkecambah (DB) dan Vigor Kekuatan Tumbuh $\left(\mathrm{V}_{\mathrm{KT}}\right)$ dengan tolak ukur Kecepatan tumbuh $\left(\mathrm{K}_{\mathrm{CT}}\right)$ dan Indeks Vigor (IV).

\section{Pengujian Vigor Daya Simpan}

Pengusangan Cepat Terkontrol. Pengusangan cepat terkontrol dilakukan dengan menaikkan kadar air benih kedelai menjadi $22 \%$ melalui penambahan air. Benih kedelai sebanyak 100 butir benih untuk setiap satuan percobaan dan air yang telah ditentukan volumenya berdasarkan rumus ISTA (2007) dimasukkan dalam kantong aluminium foil. Kantong alumunium ditutup rapat kemudian dibiarkan selama 24 jam pada suhu $5^{\circ} \mathrm{C}$ agar tercapai kadar air yang diinginkan. Benih yang telah diusangkan lalu dikecambahkan dengan metode Uji Kertas Digulung dalam Plastik (UKDdp) sebanyak 25 butir untuk setiap satuan percobaan pada germinator IPB 72-1, kemudian dilakukan pengamatan terhadap $\mathrm{V}_{\mathrm{PCT}}$. Nilai $\mathrm{V}_{\mathrm{PCT}}$ menunjukkan presentase kecambah normal benih setelah didera dengan suhu dan kadar air tinggi.

Pengujian Daya Hantar Listrik (DHL). Menurut Sadjad et al. (1999) nilai DHL merupakan salah satu penduga vigor daya simpan benih. Pengujian ini dilakukan dengan merendam 50 butir benih yang telah ditimbang pada $100 \mathrm{ml}$ air bebas ion selama 24 jam kemudian air rendamannnya diukur dengan menggunakan alat electric conductivity meter.

\section{HASIL DAN PEMBAHASAN}

\section{Kondisi Umum}

Penanaman kedelai dilakukan di Kebun Percobaan Leuwikopo IPB, Darmaga, Bogor. Masa penelitian di lapang dilakukan selama 3 bulan mulai dari awal bulan Maret sampai dengan awal bulan Juni 2011. Musim hujan berlangsung selama penelitian, sehingga di daerah penelitian 
masih mendapatkan curah hujan yang tinggi. Penyiraman hanya dilakukan selama beberapa hari setelah tanam.

Pengendalian gulma di lahan penelitian dilakukan secara manual. Gulma yang banyak ditemui di lapang antara lain Axonopus compressus, Oxalis barrelieri, Mimosa pudica, Mimosa pigra dan sebagainya. Hama yang menyerang tanaman kedelai selama penelitian antara lain belalang (terutama dari jenis Valanga $s p$. ), kepik hijau (Nezara viridula) dan kepik polong (Riptortus linearis). Selama pertanaman ditemukan juga penyakit seperti karat daun dan virus mosaik kuning. Serangan hama cukup sedikit dan tidak mengganggu pertanaman secara luas sehingga tidak dilakukan penyemprotan hama sedangkan untuk penyakit dilakukan pencabutan pada tanaman yang terserang.

Pengamatan keadaan vegetatif tanaman di lahan dimulai saat 2 MST, dan pengamatan berakhir saat tanaman memasuki masa generatif yakni 6 MST. Tanaman kedelai mulai berbunga pada 35 HST, hal ini sesuai dengan deskripsi varietas (Balitkabi, 2008). Panen dilakukan ketika telah mencapai masak fisiologis. Pemanenan dilakukan sebanyak dua kali karena tingkat kemasakan antar petak yang tidak sama, panen pertama dilakukan pada 85 HST sedangkan panen kedua dilakukan pada 91 HST. Pada varietas Anjasmoro, hal ini sesuai dengan perkiraan umur panen berdasarkan varietas (Balitkabi, 2008), yakni 82.5 - 92.5 HST, akan tetapi pada varietas Detam 1 hal ini melebihi umur panen yang seharusnya 82 HST. Curah hujan yang cukup tinggi terutama saat menjelang panen diduga menjadi penyebab umur panen kedelai varietas Detam 1 menjadi lebih panjang.

\section{Pertumbuhan Vegetatif dan Produksi Tanaman}

Rekapitulasi hasil sidik ragam komponen pertumbuhan vegetatif dan produksi dapat dilihat pada Tabel 1. Hasil uji $\mathrm{F}$ menunjukan bahwa perlakuan pemupukan dan interaksi antara varietas dengan pemupukan tidak berpengaruh nyata terhadap seluruh peubah pengamatan. Perlakuan varietas berpengaruh nyata terhadap peubah tinggi tanaman (3 - 6 MST), jumlah daun (2 - 3 MST), dan bobot benih per tanaman.

Perbedaan yang terdapat antara varietas Anjasmoro dan Detam 1 dalam penelitian ini terkait dengan sifat genetik antar varietas yang berbeda-beda dan memiliki karakteristik tersendiri seperti yang dijabarkan pada deskripsi varietasnya masing-masing. Perlakuan varietas dimaksudkan untuk mengetahui ada atau tidaknya interaksi perlakuan pemupukan dengan varietas terhadap peubah-peubah yang diamati.

Tabel 1. Rekapitulasi Sidik Ragam Pengaruh Varietas Kedelai, Jenis Pemupukan, dan Interaksinya terhadap Pengamatan Vegetatif dan Produksi

\begin{tabular}{|c|c|c|c|c|}
\hline \multirow{2}{*}{ Peubah pengamatan } & \multicolumn{3}{|c|}{ Perlakuan } & \multirow{2}{*}{$\begin{array}{l}\mathrm{KK} \\
(\%)\end{array}$} \\
\hline & $\mathrm{V}$ & $\mathrm{P}$ & $\mathrm{V} * \mathrm{P}$ & \\
\hline \multicolumn{5}{|l|}{ Tinggi Tanaman } \\
\hline $2 \mathrm{MST}$ & tn & tn & tn & 4.67 \\
\hline $3 \mathrm{MST}$ & $*$ & tn & tn & 5.78 \\
\hline $4 \mathrm{MST}$ & $*$ & tn & tn & 10.63 \\
\hline $5 \mathrm{MST}$ & $*$ & tn & tn & 10.02 \\
\hline $6 \mathrm{MST}$ & $*$ & tn & tn & 10.78 \\
\hline \multicolumn{5}{|l|}{ Jumlah Daun } \\
\hline $2 \mathrm{MST}$ & $*$ & tn & tn & 15.17 \\
\hline $3 \mathrm{MST}$ & $* *$ & tn & tn & 9.08 \\
\hline $4 \mathrm{MST}$ & tn & tn & tn & 12.21 \\
\hline $5 \mathrm{MST}$ & tn & tn & tn & 18.22 \\
\hline $6 \mathrm{MST}$ & tn & tn & tn & 17.34 \\
\hline \multicolumn{5}{|l|}{ Bobot benih per } \\
\hline tanaman & $*$ & tn & tn & 11.72 \\
\hline Bobot benih per & & & & \\
\hline petak & tn & tn & tn & 24.61 \\
\hline
\end{tabular}

Keterangan: $\mathrm{tn}=$ tidak nyata berdasarkan uji $\mathrm{F}$ pada taraf $5 \%$ $*$ = nyata berdasarkan uji $\mathrm{F}$ pada taraf $5 \% * *=$ nyata berdasarkan uji $\mathrm{F}$ pada taraf $1 \% \mathrm{~V}=$ Varietas; $\mathrm{P}=$ Pemupukan; $\mathrm{V} * \mathrm{P}=$ Interaksi antar faktor $\mathrm{KK}=$ Koefisien keragaman

Pada komponen pengamatan vegetatif yaitu tinggi tanaman dan jumlah daun mulai dari awal pertumbuhan sampai dengan panen secara umum meningkat. Hal ini menunjukan bahwa semua perlakuan pemupukan pada petak perlakuan mampu mendukung masa vegetatif tanaman kedelai. Perlakuan pemupukan tidak memberikan pengaruh nyata terhadap peubah tinggi tanaman dan jumlah daun. Hal ini diduga karena hara di dalam tanah telah mampu menyuplai hara sesuai kebutuhan tanaman, terutama untuk mendukung pertumbuhan tinggi tanaman dan penambahan jumlah daun. Ketersediaan hara yang cukup di dalam tanah sebelum penanaman diduga menjadi penyebab tidak adanya respon yang cukup nyata pada perlakuan pemupukan yang berbeda.

Bobot benih per petak varietas Anjasmoro tidak berbeda nyata dengan varietas Detam 1 tetapi memiliki bobot benih per tanaman yang nyata lebih tinggi dibandingkan varietas Detam 1. Varietas Anjasmoro memiliki bobot benih per tanaman sebesar $11.42 \mathrm{~g}$ sedangkan varietas Detam 1 hanya $9.09 \mathrm{~g}$.

Pertumbuhan organ vegetatif akan mempengaruhi hasil tanaman. Semakin besar pertumbuhan organ vegetatif yang berfungsi sebagai penghasil asimilat (source) akan meningkatkan pertumbuhan organ pemakai (sink) 
yang akhirnya akan memberikan hasil yang semakin besar pula. Hal ini sesuai dengan hasil penelitian yang menunjukan bahwa keragaan agronomis pada varietas Anjasmoro (tinggi tanaman dan jumlah daun) relatif lebih baik pertumbuhannya dibandingkan dengan varietas Detam 1 sehingga menyebabkan produksi (bobot benih per tanaman) yang lebih baik pada varietas Anjasmoro dibandingkan dengan varietas Detam 1 .

Perlakuan pemupukan pada penelitian ini tidak memberikan pengaruh yang nyata pada kedua komponen produksi, baik jumlah benih per tanaman maupun jumlah benih per petak. Hal ini diduga karena kesuburan tanah sudah cukup karena pemberian pupuk $\mathrm{N}, \mathrm{P}$, dan $\mathrm{K}$ sesuai dengan dosis rekomendasi pun tidak meningkatkan produksi.

\section{Viabilitas dan Vigor Benih yang Dihasilkan}

Viabilitas Potensial. Pengujian di laboratorium menunjukan bahwa perlakuan varietas, pemupukan maupun interaksinya tidak memberikan pengaruh yang nyata pada tolak ukur daya berkecambah. Pada Tabel 2 terlihat bahwa secara keseluruhan viabilitas potensial benih cukup bagus karena seluruhnya memiliki nilai DB lebih dari $80 \%$.

Tabel 2. Pengaruh varietas dan pemupukan terhadap mutu benih

\begin{tabular}{|c|c|c|c|c|}
\hline \multirow{2}{*}{ Perlakuan } & \multirow{2}{*}{$\begin{array}{c}\text { Viabilitas } \\
\text { Potensial } \\
\left(\mathrm{V}_{\mathrm{P}}\right)\end{array}$} & \multicolumn{2}{|c|}{$\begin{array}{l}\text { Vigor Kekuatan } \\
\text { tumbuh }\left(\mathrm{V}_{\mathrm{KT}}\right)\end{array}$} & \multirow{2}{*}{$\begin{array}{c}\text { Vigor Daya } \\
\begin{array}{c}\text { Simpan } \\
\left(\mathrm{V}_{\mathrm{DS}}\right)\end{array} \\
\mathrm{V}_{\mathrm{PCT}}(\%)\end{array}$} \\
\hline & & $\begin{array}{c}\text { KCT } \\
\left(\% \text { etmal }^{-1}\right)\end{array}$ & IV $(\%)$ & \\
\hline \multicolumn{5}{|l|}{ Varietas } \\
\hline Anjasmoro & 80.00 & 28.64 & 69.07 & 74.13 \\
\hline Detam 1 & 86.93 & 28.44 & 77.33 & 72.53 \\
\hline \multicolumn{5}{|l|}{ Pemupukan } \\
\hline $\begin{array}{l}\text { Tanpa } \\
\text { pupuk }\end{array}$ & 85.33 & 27.78 & 78.00 & $61.33 \mathrm{~b}$ \\
\hline NPK & 88.67 & 28.86 & 78.67 & $83.33 \mathrm{a}$ \\
\hline NP & 81.33 & 30.30 & 71.33 & $70.00 \mathrm{ab}$ \\
\hline NK & 82.00 & 27.72 & 70.67 & $80.00 \mathrm{a}$ \\
\hline PK & 80.00 & 28.07 & 67.33 & $72.00 \mathrm{ab}$ \\
\hline Interaksi & tn & tn & $\operatorname{tn}$ & $\operatorname{tn}$ \\
\hline KK (\%) & 9.20 & 9.73 & 14.68 & 16.51 \\
\hline Keterangan : & $\begin{array}{l}\text { Angka yar } \\
\text { kolom di } \\
\text { berbeda ny }\end{array}$ & $\begin{array}{l}\mathrm{g} \text { diikuti } \\
\mathrm{n} \text { perlaku } \\
\text { ata pada } \mathrm{uj}\end{array}$ & $\begin{array}{l}\text { uruf yan } \\
n \text { yang }\end{array}$ & $\begin{array}{l}\text { sama pada } \\
\text { sama tidak } \\
\text { f } 5 \%\end{array}$ \\
\hline
\end{tabular}

Vigor Kekuatan Tumbuh. Indeks vigor dan kecepatan tumbuh menggambarkan vigor kekuatan tumbuh benih. Hasil penelitian menunjukan bahwa nilai IV dan $\mathrm{K}_{\mathrm{CT}}$ tidak dipengaruhi oleh perlakuan varietas maupun pemupukan. Tidak ada pengaruh interaksi antara kedua perlakuan tersebut baik terhadap IV maupun $\mathrm{K}_{\mathrm{CT}}$.

Vigor Daya Simpan berdasarkan Metode Pengusangan Cepat Terkontrol. Pada penelitian ini untuk menggambarkan vigor daya simpan benih dilakukan dengan menggunakan metode Controlled Deterioration sehingga hal ini dapat menduga perbedaan viabilitas benih setelah melewati suatu periode penyimpanan. Harrington (1972) menyatakan bahwa suhu dan kadar air tinggi merupakan faktor penyebab menurunnya daya berkecambah dan vigor. Benih yang memiliki vigor daya simpan yang tinggi akan tetap memiliki peformansi yang baik dibandingkan benih yang bervigor rendah meskipun didera pada suhu dan kadar air yang tinggi.

Mutu benih tidak berbeda nyata dalam hal viabilitas potensial yang ditunjukkan dengan tolak ukur DB, maupun vigor kekuatan tumbuh yang ditunjukan dengan tolak ukur $\mathrm{K}_{\mathrm{CT}}$ dan IV, walaupun demikian pemupukan ternyata memberikan pengaruh yang nyata terhadap $\mathrm{V}_{\mathrm{PCT}}$ yang mengindikasikan vigor daya simpan benih $\left(\mathrm{V}_{\mathrm{DS}}\right)$. Berdasarkan Tabel 2, Pemupukan lengkap NPK $(83.33 \%)$ dan NK $(80.00 \%)$ menghasilkan benih dengan vigor daya simpan yang nyata lebih tinggi dibandingkan dengan perlakuan tanpa pupuk (61.33\%), sedangkan pemupukan NP dan PK tidak berbeda nyata dengan perlakuan tanpa pemupukan.

Tercukupinya kebutuhan hara di dalam tanah untuk mendukung pertumbuhan vegetatif bahkan produksi tanaman hingga viabilitas potensial dan vigor kekuatan tumbuh benih, belum cukup untuk menghasilkan benih yang tahan terhadap deraan, khususnya deraan terhadap pengusangan cepat terkontrol. Penambahan hara NK dapat meningkatkan $\mathrm{V}_{\mathrm{PCT}}$ secara nyata. NK adalah unsur yang paling perlu ditambahkan pada tanah. Pada penelitian ini ketersediaan $\mathrm{P}$ pada tanah diduga sudah cukup dan mampu menyuplai kebutuhan hara $\mathrm{P}$ bagi tanaman, karena penambahan NK (tanpa P) $(80.00 \%)$ sudah mampu memberikan peningkatan yang nyata dibandingkan dengan kontrol $(61.33 \%)$ dan tidak berbeda nyata dengan NPK $(83.33 \%)$.

Vigor Daya Simpan berdasarkan Nilai Daya Hantar Listrik. Sifat genetik benih antara lain tampak pada permeabilitas dan warna kulit benih yang berpengaruh terhadap daya simpan benih kedelai. Daya simpan merupakan perkiraan waktu benih mampu untuk disimpan. Benih yang mempunyai daya simpan lama berarti mampu melampaui periode simpan yang panjang dan benih yang setelah penyimpanan masih memiliki 
kekuatan tumbuh yang tinggi dikatakan memiliki vigor daya simpan $\left(\mathrm{V}_{\mathrm{DS}}\right.$ ) yang tinggi (Sadjad et al. 1999). Pengujian DHL merupakan salah satu parameter yang dapat mengindikasikan vigor daya simpan benih. Menurut ISTA (2007) semakin tinggi nilai daya hantar listriknya maka viabilitas benih semakin menurun, hal ini diakibatkan karena makin besar pula kebocoran elektrolit pada benih.

Masing-masing unsur N, P, dan $\mathrm{K}$ memiliki peran dalam mendukung permeabilitas benih. Rosmarkam dan Yuwono (2002) mengemukakan pentingnya unsur $\mathrm{K}$ dalam meningkatkan kadar lignin. Dalam hal ini Marwanto (2003) menyatakan bahwa benih kedelai yang memiliki kandungan lignin lebih tinggi mempunyai vigor daya simpan yang lebih baik. Menurut Hartawan et al. (2011) kandungan protein berkorelasi negatif dengan nilai DHL. Kandungan protein yang tinggi pada membran sel akan meningkatkan integritas membran sel sehingga tidak banyak mengalami kebocoran. Peningkatan protein pada benih kedelai dipengaruhi oleh serapan nitrogen oleh bakteri Rhizobium dan fiksasi nitrogen. Dalam hal ini, unsur P berperan penting sebagai komponen ATP yang merupakan sumber energi dalam fiksasi nitrogen, dan sebagai komponen penyusun protein.

Hasil analisis statistik menunjukan bahwa faktor tunggal varietas maupun pemupukan tidak berpengaruh nyata terhadap DHL akan tetapi terdapat interaksi antara varietas dengan pemupukan yang berpengaruh nyata terhadap DHL. Tabel 3 menunjukan adanya interaksi antara varietas dan perlakuan pemupukan. Berdasarkan nilai rataan yang diperoleh, varietas Detam 1 memiliki nilai DHL yang lebih rendah dibandingkan dengan varietas Anjasmoro. Perbedaan nyata antara kedua varietas terlihat pada perlakuan pemupukan NP yang menunjukkan bahwa Varietas Detam 1 memiliki nilai DHL yang lebih rendah dengan 108.68 $\mu$ mhos $\mathrm{cm}^{-1} \mathrm{~g}^{-1}$ berbeda nyata dengan varietas Anjasmoro yang memiliki nilai DHL 172.88 $\mu$ mhos $\mathrm{cm}^{-1} \mathrm{~g}^{-1}$. Hal ini menunjukan bahwa varietas Detam 1 (kedelai hitam) cenderung memiliki nilai DHL yang lebih rendah dibandingkan dengan varietas Anjasmoro (kedelai kuning), artinya permeabilitas membran dan vigor daya simpan pada kedelai hitam khususnya pada perlakuan NP lebih baik dibandingkan dengan kedelai kuning.
Tabel 3. Pengaruh interaksi pemupukan dan varietas terhadap daya hantar listrik benih kedelai

\begin{tabular}{|c|c|c|c|}
\hline \multirow{2}{*}{ Perlakuan } & \multicolumn{2}{|c|}{ Varietas } & \multirow{2}{*}{ Rataan } \\
\hline & Anjasmoro & Detam 1 & \\
\hline \multicolumn{4}{|l|}{ Tanpa } \\
\hline pupuk & 139.34 Aab & 127.93 Aab & 133.635 \\
\hline NPK & $134.28 \mathrm{Ab}$ & $139.51 \mathrm{Aa}$ & 136.895 \\
\hline NP & $172.88 \mathrm{Aa}$ & $108.68 \mathrm{Bb}$ & 140.78 \\
\hline NK & $107.57 \mathrm{Ab}$ & 118.01 Aab & 112.79 \\
\hline PK & $126.44 \mathrm{Ab}$ & 125.31 Aab & 125.875 \\
\hline Rataan & 136.102 & 123.888 & \\
\hline \multicolumn{4}{|c|}{$\begin{array}{l}\text { Keterangan: Angka-angka sekolom yang diikuti oleh huruf } \\
\text { kecil yang sama tidak berbeda nyata dan angka- } \\
\text { angka sebaris yang diikuti oleh huruf besar } \\
\text { yang sama tidak berbeda nyata pada uji DMRT } \\
\\
\alpha=5 \% \text {. }\end{array}$} \\
\hline
\end{tabular}

\section{Kandungan Antosianin}

Antosianin merupakan salah satu antioksidan. Antioksidan diduga berguna untuk mempertahankan viabilitas benih karena memiliki kemampuan untuk mengurangi efek radikal bebas yang terbentuk selama penyimpanan. Berdasarkan analisis statistik pada Tabel 4 diketahui bahwa kandungan antosianin berbeda sangat nyata pada dua varietas yang diuji.

Tabel 4. Pengaruh Pemupukan dan Varietas terhadap Kandungan Antosianin

\begin{tabular}{rcc}
\hline Perlakuan & $\begin{array}{c}\text { Kandungan antosianin }\left(\mu \mathrm{mol} 100 \mathrm{~g}^{-1}\right) \\
\text { Rata-rata } \pm \text { standar } \\
\text { deviasi }\end{array}$ & Uji DMRT \\
\hline Anjasmoro & \\
Tanpa pupuk & $0.519 \pm 0.0963$ \\
NPK & $0.566 \pm 0.5658$ \\
NP & $0.371 \pm 0.138$ & $0.418 \mathrm{~b}$ \\
NK & $0.282 \pm 0.0992$ & \\
PK & $0.354 \pm 0.1014$ \\
\hline Rata-rata & $0.418 \pm 0.1196$ \\
\hline Detam 1 & \\
Tanpa pupuk & $1.151 \pm 0.411$ \\
NPK & $1.373 \pm 0.1656$ \\
NP & $1.225 \pm 0.2106$ \\
NK & $1.779 \pm 0.6979$ \\
PK & $1.011 \pm 0.1138$ \\
\hline Rata-rata & $1.308 \pm 0.2939$ \\
\hline Keterangan : Angka yang diikuti huruf yang sama pada \\
\multicolumn{3}{c}{ perlakuan yang sama tidak berbeda nyata } \\
pada uji DMRT taraf $5 \%$
\end{tabular}

Kandungan antosianin pada varietas kedelai hitam yaitu Detam $1\left(1.308 \mu \mathrm{mol} 100 \mathrm{~g}^{-1}\right)$ nyata lebih tinggi dibandingkan pada kedelai kuning yaitu Anjasmoro $\left(0.418 \mu \mathrm{mol} 100 \mathrm{~g}^{-1}\right)$. Hal ini sesuai dengan pernyataan Futura et al. (2002) yang menyatakan bahwa kedelai hitam mengandung banyak antosianin. Adanya 
perbedaan kandungan antosianin benih diakibatkan karena faktor genetik pada benih kedelai oleh warna kulit benihnya. Hasil tersebut juga sejalan dengan hasil penelitian Agustin (2010) yang menyatakan bahwa kandungan antosianin pada kedelai hitam varietas Detam 1 nyata lebih tinggi dibandingkan kedelai kuning varietas Anjasmoro.

Berdasarkan analisis statistik perlakuan pemupukan maupun interaksi antara varietas dengan pemupukan tidak memberikan pengaruh yang nyata terhadap kandungan antosianin benih, hasil ini mirip dengan penelitian Mualim et al. (2009) yang menyatakan bahwa perlakuan pemupukan tidak berpengaruh nyata terhadap kandungan antosianin daun tetapi hanya berpengaruh nyata terhadap produksi antosianin tanaman kolesom. Pemupukan NP (tanpa K) menghasilkan rata-rata produksi antosianin daun kolesom terendah (18.90 mol per tanaman) dan berbeda nyata dengan perlakuan lainnya. Hal ini menunjukkan pada penelitian tersebut unsur $\mathrm{K}$ sebagai faktor pembatas produksi antosianin daun kolesom. Pada penelitian ini diduga karena tanah telah menyediakan kandungan hara yang cukup bagi pertumbuhan kedelai, sehingga baik unsur $\mathrm{N}$, $\mathrm{P}$, maupun $\mathrm{K}$ tidak menjadi faktor pembatas pembentukan antosianin. Menurut Delgado et al. (2006) aplikasi K dalam dosis yang tinggi bahkan dapat menurunkan kandungan antosianin. Hal ini juga menunjukan bahwa dalam pembentukan antosianin tanaman kedelai kurang respon terhadap pemupukan.

\section{Hubungan Antara Kandungan Antosianin dengan Vigor Daya Simpan Benih}

Tingginya kandungan antosianin dan permeabilitas benih yang lebih baik (nilai DHL rendah) pada kedelai hitam seharusnya mengindikasikan vigor daya simpan yang baik pula. Menurut Purwanti (2004), kebocoran membran sel akibat deteriorasi menyebabkan penurunan vigor dipercepat. Semakin lama benih disimpan semakin bertambah tua sel-sel dalam benih. Proses penuaan pada kedelai kuning yang disimpan pada suhu tinggi nampak dipercepat dibanding kedelai hitam, sehingga kebocoran membran sel-sel benih semakin tinggi dan permeabilitas sel juga menurun. Heatherly et al. (1995) juga mengatakan bahwa benih yang memiliki kulit yang kurang permeabel lebih mampu mempertahankan viabilitas dan vigor benih, namun hasil penelitian ini menunjukan bahwa $\mathrm{V}_{\mathrm{PCT}}$ Anjasmoro yang tidak berbeda nyata dengan $\mathrm{V}_{\mathrm{PCT}}$ Detam 1. Hal ini diduga bahwa $\mathrm{V}_{\mathrm{PCT}}$ yang digunakan tidak cukup peka untuk membedakan vigor daya simpan antar varietas tetapi lebih peka dalam membedakan vigor daya simpan antar perlakuan pemupukan. Berdasarkan hasil ini maka uji korelasi dilakukan pada masingmasing varietas secara terpisah. Hasil korelasi antara kandungan antosianin benih dengan vigor daya simpan benih melalui uji DHL dan pengusangan cepat terkontrol dapat dilihat pada Tabel 5.

Tabel 5. Nilai Korelasi Kandungan Antosianin dengan Vigor Daya Simpan Benih

\begin{tabular}{lcc}
\hline \multirow{2}{*}{ Tolak ukur } & \multicolumn{2}{c}{ Varietas } \\
\cline { 2 - 3 } & \multicolumn{1}{c}{ Anjasmoro } & Detam 1 \\
\hline --------Koefisien Korelasi $(\mathrm{r})----------$ \\
\hline $\begin{array}{l}\text { Daya Hantar Listrik } \\
\left(\mu \text { mhos cm } \mathrm{g}^{-1}\right)\end{array}$ & $0.10218^{\mathrm{tn}}$ & $\begin{array}{c}0.08962^{\mathrm{t}} \\
\mathrm{n}\end{array}$ \\
$\begin{array}{l}\text { Pengusangan Cepat } \\
\text { Terkontrol }(\%)\end{array}$ & $0.03489^{\mathrm{tn}}$ & $\begin{array}{c}0.27341^{\mathrm{t}} \\
\mathrm{n}\end{array}$ \\
\hline Keterangan $: \mathrm{tn}=$ tidak berpengaruh nyata &
\end{tabular}

Aktivitas antioksidan yang dimiliki antosianin diduga dapat meningkatkan vigor daya simpan benih, namun hasil pengujian statistik menunjukan bahwa kandungan antosianin tidak berkolerasi dengan vigor daya simpan benih baik melalui uji DHL pada varietas Anjasmoro $(\mathrm{r}=$ $\left.0.10218^{\mathrm{tn}}\right)$ dan varietas Detam $1\left(\mathrm{r}=0.08962^{\mathrm{tn}}\right)$, maupun melalui pengusangan cepat terkontrol pada varietas Anjasmoro $\left(\mathrm{r}=0.03489^{\mathrm{th}}\right)$ dan varietas Detam $1\left(\mathrm{r}=0.27341^{\mathrm{tn}}\right)$ (Tabel 5). Hasil penelitian ini menunjukan bahwa kandungan antosianin pada varietas Anjasmoro maupun Detam 1 tidak bisa menduga vigor daya simpan benih kedelai yang dipengaruhi perlakuan pemupukan (mutu fisiologis) baik melalui uji DHL maupun melalui uji pengusangan cepat terkontrol.

Kandungan antosianin varietas Anjasmoro dan Detam 1 berbanding terbalik dengan nilai daya hantar listriknya. Varietas Detam 1 memiliki kandungan antosianin yang tinggi dengan nilai DHL yang rendah, sebaliknya varietas Anjasmoro memiliki kandungan antosianin yang rendah dengan nilai DHL yang tinggi. Hal ini sejalan dengan hasil penelitian Agustin (2010) yang menyatakan bahwa kandungan antosianin pada berbagai varietas kedelai hitam dan kuning (mutu genetik) memiliki korelasi negatif dan erat terhadap tolak ukur daya hantar listrik $(\mathrm{r}=-0.65)$. 


\section{KESIMPULAN}

Hasil penelitian menunjukkan bahwa kombinasi pemupukan $\mathrm{N}, \mathrm{P}$, dan $\mathrm{K}$ berpengaruh nyata terhadap vigor daya simpan benih melalui pengusangan cepat terkontrol. Pemupukan lengkap NPK dan NK akan menghasilkan benih dengan vigor daya simpan yang nyata lebih tinggi dibandingkan dengan perlakuan tanpa pupuk, sedangkan pemupukan NP dan PK tidak berbeda dengan perlakuan tanpa pupuk.

Pemupukan NPK tidak mempengaruhi kandungan antosianin pada akhir kemasakan baik pada varietas Anjasmoro maupun Detam 1. Varietas Detam 1 memiliki kandungan antosianin yang nyata lebih tinggi dibanding varietas Anjasmoro. Sebaliknya, pada pengujian DHL terdapat interaksi yang menunjukkan indikasi bahwa varietas Detam 1 memiliki nilai DHL yang lebih rendah dibandingkan dengan varietas Anjasmoro sehingga diduga varietas Detam 1 memiliki vigor daya simpan yang lebih baik. Pada penelitian ini juga diketahui bahwa tidak ada korelasi nyata antara kandungan antosianin dengan vigor daya simpan benih.

\section{DAFTAR PUSTAKA}

Agustin, H. 2010. Hubungan antara Kandungan Antosianin dengan Ketahanan Benih terhadap Pengusangan Cepat Beberapa Varietas Kedelai. Skripsi. Departemen Agronomi dan Hortikultura, Fakultas Pertanian, IPB. Bogor. 39 hal.

Badan Pusat Statistik. 2011. Produksi padi, jagung, dan kedelai. http://www.bps.go.id. [22 Oktober 2011].

Balai Penelitian Tanah. 2010. Rekomendasi pemupukan tanaman kedelai pada berbagai tipe penggunaan lahan. http://balittanah.litbang.deptan.go.id. [1 Januari 2011].

Balitkabi. 2008. Deskripsi Varietas Unggul Kacangkacangan dan Umbi-umbian. Balai Penelitian Tanaman Kacang-kacangan dan Umbiumbian. Malang. 171 hal.

Copeland, L.O. and M. B. McDonald. 2001. Principles of Seed Science and Technology. Burgess Publishing Company. New York. 467 p.

Delgado, R., M. Gonzalez, P. Martin. 2006. Interaction effects of nitrogen and potassium fertilization on anthocyanin composition and chromatic features of tempranillo grapes. Int. J. Vine Wine. Sci. 40:141-150.
Departemen Pertanian. 2010. Pedoman Pelaksanaan Pengembangan Perbenihan Tanaman Pangan. Direktur Jenderal Tanaman Pangan Departemen Pertanian. Jakarta. 86 hal.

Futura, M., Yano, Y. Gabazza, E. C., Araki-Sasaki, R. 2002. The potential of anthocyanin from black soybean seed coat.[internet] [diunduh 2011 Jan 29] http://onlinelibrary.wiley.com.

Harrington, J.F. 1972. Seed Storage and Longevity, Seed Biology, Vol. III, In Ed Kozlowsky, T.T., Academic Press New York.

Hartawan, R., Z. R. Djafar, Z. P. Negara, M. Hasmeda, Zulkarnain. 2011. Pengaruh panjang hari, asam indol asetat, dan fosfor terhadap tanaman kedelai dan kualitas benih dalam penyimpanan. J. Agron. Indonesia 39(1):7-12.

Heatherly, L. G., M. M. Kenthy, T. C. Killen. 1995. Effect of storage environment and duration on permeable seed coat in soybean. Field Crops. Res. 40 (1):57-62.

ISTA. 2007. International Rule for Seed Testing. Edition 2007. International Seed Testing Association. Zurich. Switzerland.

Kartono. 2004. Teknik penyimpanan benih kedelai varietas Wilis pada kadar air dan suhu penyimpanan berbeda. Bul. Teknik Pertanian 9:79-82.

Marwanto. 2003. Hubungan antara kandungan lignin kulit benih dengan permeabilitas dan daya hantar listrik rendaman benih kedelai. Jurnal Akta Agrosia 6(2):51-54.

Mitrowihardjo, S. 1997. Inhibition of soy bean (Glycine max (L.) Merr.) seed deteration using antioxidant under different accelerated and natural aging. Ilmu-ilmu Pertanian 6(1): 8-16.

Mualim, L., S. A. Aziz, M. Melati. 2009. Kajian pemupukan NPK dan jarak tanam pada produksi antosianin daun kolesom. J. Agron. Indonesia 37(1):55-61.

Purwanti, S. 2004. Study of storage temperature on the quality of black and yellow soybean seed. Jurnal Ilmu Pertanian 11(1): 22-31.

Rosmarkam, A., N. W. Yuwono. 2002. Ilmu Kesuburan Tanah. Yogyakarta(ID): Kanisius. 224 hal.

Sadjad, S., E. Muniarti, S. Ilyas. 1999. Parameter Pengujian Vigor Benih dari Komparatif ke Simulatif. Jakarta(ID): Grasindo. 185 hal. 
Sims, D. A., J. A. Gamon. 2002. Relationships between leaf pigment content and spectral reflectance across a wide range of species, leaf structures and developmental stages. Remote Sensing of Environment 81:337-354.
Wahyuni, A. 2011. Hubungan antara Kandungan Klorofil dengan Ketahanan Benih terhadap Pengusangan Cepat pada beberapa Varietas Kedelai (Glycine max (L.) Merr). Skripsi. Departemen Agronomi dan Hortikultura, Fakultas Pertanian, IPB. Bogor. 43 hal. 